\title{
Alternatif Bir Haber Dergisi Olarak (Post) Express
}

\author{
Ar. Gör. Umur BEDiR \\ Ar. Gör. Emre Tansu KETEN
}

galatasaray üniversitesi medya ve iletişim çalışmaları doktora öğrencisi umurbedir@hotmail.com marmara üniversitesi sosyal bilimler enstitüsü genel gazetecilik anabilim dalı doktora öğrencisi emretansuketen@gmail.com

\section{Abstract}

\section{(Post) Express as an alternative news magazine}

In this study, it is examined how and in what ways the (post) Express revealed an alternative media activity along the twenty years in which it has continued its publication. In this context, the financial and administrative structure and content production style of Express is examined by considering the historical background of 1980's and 90's media and more spesifically news magazine publishing and also using the outputs of personel interviews with founding members of the magazine. As a result of this research, it is concluded that Express as an alternative medium is financially independent, adopt a horizontal organizational form based on friendship and allowing participation and also have an inclusivist sense of representation that include other social groups excluded by mainstream media.

keywords: alternative media, express magazin 


\section{Résumé}

\section{(Post) Express , un magazine alternatif d'information}

Dans cette étude, il s'agit de montrer de quelle manière on peut parler du magazine d'information (post) Express, publié pendant 20 ans, en tant qu'une éditon alternative. Pour ce faire, nous analyserons la structure financière et administrative du magazine Express, sa production de contenu, la situation du média et spécifiquement des magazines d'information entre les années 1980 et 1990 tout en nous informant sur le contexte historique et nous appuyant sur la témoignage des éditeurs. Cette recherche nous montre que le magazine Express n'est pas financièrement dépendant et se contruit sur l'amitié avec une organisation horizontale, ouverte à la participation de tous et donne voix aux minorités exclues par les médias traditionnels.

mots-clés : média alternatif, magazine express, magazine d'information

\section{Özet}

Bu çalışmada haber dergisi (post) Express'in, yayın hayatını sürdürdügü 20 sene boyunca, hangi yönleriyle ve nasıl bir alternatif yayıncılık faaliyeti ortaya koyduğu incelenmiştir. Bu bağlamda Express dergisinin mali ve idari yapısı ve içerik üretim mantığı, dergivi ortaya çıkaran 80 ve 90'lı yıllarda medyanın ve özel olarak haber dergiciliğinin durumuna ilişkin tarihsel arka plan da göz önünde bulundurularak ve dergi kurucularıyla yapılan kişisel görüşmelerin bulgularından faydalanılarak incelenmiştir. Araştırma sonucunda, alternatif bir mecra olarak Express dergisinin mali açıdan bağımsız olduğu, dostluk temeline dayanan, yatay ve katııma izin veren bir örgütlenme biçimini benimsediği ve ana akım medyadan dışlanan toplumsal kesimleri de içine alan kapsayıcı bir temsil rejimine sahip olduğu ortaya konulmuştur.

anahtar kelimeler: alternatif medya, express dergisi, haber dergiciliği 


\section{Giriş}

Iletişim bilimleri literatüründe "alternatif medya" kavramının neyi işaret ettiği tartışmalı bir konudur. Kimi yazarlar, bu kavramsallaştırma ile yerleşik ve kurumsallaşmış siyasetlere karşı geliştirilen alternatif ve köktenci siyasetlerin yayın faaliyetlerine dikkat çekerek, siyasi bir sınırlama içerisine girmekte (Mutlu, 1998: 35); kimileri ise, özellikle son dönem yaygınlaşan şekliyle, geleneksel kitle iletişim araçlarına alternatif olarak konumlanan yeni medya ortamlarına vurgu yaparak, araçsal bir alan çizmeye çalışmaktadır.

Bu tartışmalar içerisinde, özellikle, medya kuruluşlarının ekonomik özerkliğinin/özgürlüğünün, alternatif bir yayın olarak kabul edilebilmesi için gerekli bir özellik olarak ön plana çıkartılması dikkat çekmektedir. Örneğin, Downing, alternatifmedyakuruluşlarınınsadecemedyatekellerindendeğilkomünist/sosyalist partilerden de mali olarak bağımsız olması gerektiğini savunmaktadır (Downing, 1984: 17). Dragon ise, bu görüşü üçüncü medya kavramıyla tanımlamaktadır. Ona göre birinci medya, medya tekellerinin bünyesindeki kuruluşları, ikinci medya ise komünist/sosyalist partilere bağlı kuruluşları nitelendirmektedir. Üçüncü medya ise, üç dünya teorisinin tahayyülündeki üçüncü dünya ülkelerine (bağlantısızlar) benzer şekilde, bu iki cepheden de bağımsız, ancak birbiriyle dayanışma içinde olan bir yapıda olmalıdır (Ceyhan, 2013: 89).

Alternatif medya alanını, alternatif siyasi mücadelelerle sınıllayanlarla, apolitik bir şekilde finansal bağlantısızlıkla nitelendiren bu yaklaşımlar birlikte değerlendirildiğinde, alternatif medya alanının özellikleri idari, mali ve içeriksel olarak üç başlıkta toplanabilir. Söz konusu özellikleri en net biçimde Bailey, Cammaerts ve Carpentier'in ana akım medya ile alternatif medyayı karşılaştıran yaklaşımında görmek mümkündür;

- Ana akım;

- Büyük ölçekli, geniş ve türdeşleştirilen bir izleyici kitlesine yönelmiş,

- Devlete bağlı kurumlardan veya ticari şirketlerden meydana gelen,

- Profesyonel kadrolardan müteşekkil hiyerarşik biçimde yapılanmış,

- Baskın söylem ve temsillerin taşıyıcısı olan kurumlar olarak nitelenebilir.

- Buna karşı alternatif olarak nitelendirilebilecek medyaların özelliği ise şöyle sıralanmaktadır;

- Küçük ölçekli ve çeşitliliklerine saygı duyulması suretiyle dezavantajı gruplara, özel topluluklara yönelme.

- Devletten ve piyasadan bağımsız olma.

- Demokrasi ve çeşitlilik ilkeleri çerçevesinde izleyicilerin erişimini ve katılımını kolaylaştıran hiyerarşik olmayan örgütlenme yapısına sahip olma.

- Öz-temsilin öneminin vurgulanması ve baskın olmayan (hatta karşıhegemonik) söylem ve temsilleri barındırma (Bailey vd. 2008, 18). 
Alternatif bir yayın faaliyeti, her şeyden önce, ana akım medya kuruluşları içerisindeki üretim ilişkilerine bir alternatif sunmak durumundadır. Eşit işe eşit ücret, sendikalaşma, hiyerarşinin olmadığı bir çalışma ortamı ve hepsinden önemlisi "iş ilişkisi" denilen "yakınlık" kategorisinin yerine dostluk/yoldaşlık, alternatif bir yayın faaliyetinin içinde barındırması gereken koşullarıdır. Ana akım medya kuruluşlarındaki keskin hiyerarşi, editörler ve yöneticiler tarafından oluşturulan yeni aristokrasi, aynı işi yapanlar arasındaki ücret uçurumları ve sendikasız çalışma koşulları, bu kuruluşlarda çalışan medya emekçilerinin dürüst ve nitelikli bir gazetecilik/habercilik pratiği yapmasını engellemektedir (Adaklı, 2010: 84-85).

İkinci olarak, alternatif medya kuruluşları, mali olarak devlet, holding veya banka patronunun finansörlüğünde olmamalıdır. Buradaki temel kıstas, büyük sermaye gruplarından bağımsız, ekonomik silahlarla etkilenemeyecek bir yapı ortaya koyabilmektir.

Son olarak alternatif bir yayın faaliyeti, içerik üretimi olarak ana akım medyadan farklılaşmalıdır. Haber/konu seçimi, içerik dağılımı, haber sunum yöntemleri, haber söylemi, fotoğraf kullanımı gibi birçok başlıkta alternatif bir yayın, ana akımdan farklılaşmalıdır. Aslında alternatif yayınların bu özelliği, bir öncekiyle tamamen bağlantıııır. Medyaya ekonomi-politik yaklaşımın savunduğu gibi, medya endüstrisinin üretim yapısı ve üretim ilişkileri, tek tek kapitalistlerin niyetinden bağımsı olarak, ürünün içeriğini de belirlemektedir (Yaylagül, 2009: 172). Egemen üretim tarzının dışarısında konumlanamayan bir yayıncılık faaliyetinin, politik ve toplumsal hegemonik söylemin dışına çıkması da mümkün olmamaktadır.

Bu çalışma, Express dergisinin bu üç başıktan ikisi (mali ve idari yapı) açısından alternatif medya kategorisine ne ölçüde dahil edilebileceği sorusu üzerine kuruludur. Express dergisini, bu anlamda dikkate değer kılan birinci özelliği, dergiyi kuran kadroların, çeşitli ana akım medya kuruluşlarından koparak bir araya gelip, böyle bir dergiye hayat vermeleridir. Özellikle 1980'lerde yayımlanan Nokta dergisinde buluşup, sonrasında çeşitli ana akım medya kuruluşlarına dağılan bir grup gazeteci, medyanın giderek holdingleştiği bu dönemde, yıllar sonra buluşarak, kendi sermayeleriyle Express'i oluşturmuşlar ve ana akım haber dergiciliğine alternatif bir dergicilik faaliyetine başlamışlardır. Derginin ikinci özelliği ise alternatif medya sahasında oldukça geniş bir yer kaplayan siyasi örgütlenmeler tarafından çıkartılan yayınların aksine, hiç bir siyasi örgüte bağlı olmadan bu kadar uzun bir süre yayınclık faaliyetini devam ettirebilmesidir (Göktürk, Aralık 2013). Türkiye'nin alternatif medya sahası incelendiğinde, herhangi bir siyasi örgüt veya demokratik kitle örgütü tarafından finanse edilmeyen yayınların azlığı dikkat çekicidir (Sözeri, 2007: 125). Bu noktayı vurgulamaktaki amaç, çok çeşitli gelir kaynakları bulunan siyasi örgütlenmelerin aksine sadece reklam ve satış gelirleriyle ayakta kalmak durumunda olan Express 
tarzı yayınların, maddi anlamda içinde bulunduğu dezavantajlı konumu ortaya koymaktır ${ }^{1}$.

Bu çalışmada, Express dergisi, mali ve idari yapısı, organizasyon biçimi ve içerik üretim süreçlerinde temel aldığı gazetecilik anlayış ve pratiği açısından, 1980 sonrası medyanın ve özellikle haber dergiciliği pratiklerinin görünümüne ilişkin tarihsel arka plan da göz önünde bulundurularak incelenmiştir. Dergi kurucularından ve yazar kadrosundan isimlerle gerçekleştirilen yarı yapılandııımış kişisel görüşmeler araştırmanın temel ve özgün verilerini oluşturmaktadır. Alternatif medya bağlamında üçüncü kategoriyi oluşturan "içerik" başlığı ise bu araştırmanın kapsamı dışında tutulmuştur. Direkt olarak dergi içeriğinin incelenmesinden ziyade, içerik tercihini belirleyen ilkeler ve gazetecilik pratikleri üzerinde durulmuştur.

Express dergisini ele almadan önce, bu yayını ortaya çıkaran tarihsel süreci ele almakta yarar bulunmaktadır. Özellikle medyada tekelleşme-holdingleşme eğilimlerinin ve siyasi baskıların, kendini iyiden iyiye hissettirdiği 1980 sonrası süreçte, Türkiye'de haber dergiciliği faaliyetlerinin nasıl bir seyir izlediği sorusu araştırma açısından merkezi bir öneme sahiptir.

\section{Türkiye'de Haber Dergiciliği}

Türkiye'de 1831 yılında ilk gazetenin yayımlanmasından kısa bir süre sonra, 1849-51 yılları arasında -Türkçe olarak- yayımlanan ilk dergi Vakayi-i Tıbbiye'dir. 28 sayı çıkartılan bu dergi, tıp bilimiyle ilgili yazılara ve çevirilere yer vermiştir. Genel olarak bakıldığında, Osmanlı dönemi dergiciliği, Vakayi-i Tıbbiye'ye benzer bir şekilde, bilim, kültür ve sanat gibi alanları konu edinmiş, siyasetten uzak durarak ansiklopedist bir yayıncılık anlayışıyla var olmuştur (Toprak, 1984: 16).

Türkiye basın tarihine bakıldığında, dergiciliğin Cumhuriyet'in ilk yıllarıyla birlikte popülerleşmeye başladığı, dergi sayısının ve çeşidinin bu dönem arttığı görülmektedir. Haber dergisi olarak nitelenebilecek ilk Türkçe yayın 15 Mayıs 1954 tarihinde, Time dergisinden esinlenerek kurulan Akis'tir. Metin Toker yönetiminde çıkartılan ve ilk dönemler Demokrat Parti iktidarına yakın bir yayın politikası izleyen Akis, zaman içerisinde DP muhalifi bir konuma geçmiş, bu nedenle 1959 senesinde bir ay süreyle kapatılmıştır (Topuz, 2014: 206). Akis'in 27 Mayıs'ın hemen ardından çıkan ve askeri darbenin öyküsünü anlatan sayısı 150 bin satmıştır. 1967 yılında çeşitli yeniliklere giderek yazar kadrosunu genişleten dergi, 1968 yılında ekonomik nedenlerle kapanmıştır (Kalyoncu, 2004). Akis'in ilk sayısında derginin amacı şöyle dile getirilmiştir:

1 Hala yayın hayatına devam etmekte olan Yeni Harman ve Spot gibi dergiler, hiçbir sermaye grubuna, siyasi parti ve örgüte dayanmadan alternatif yayıncılık yapmaları bağlamında istisna olarak görülebilir. 
Bir aktüalite dergisi medyana getirmek. Bir aktüalite mecmuası ki onu okuyan münevver, kendisini alakadar eden her mevzuu bulabilsin. Bir hafta içinde yurtta olup bitenleri toplu halde gözden geçirebilsin. Bizim 'münevver'den anladığımız, kuyusunun dibinde yaşayan alim değildir. Çeşitli mevzularda derinliğinden ziyade genişliğine bir fikir sahibi bulunan, politikaya da meraklı, maça da giden, iktisadi meseleleri de takip eden, sinemayı da seven, kitap okuyan, hadiseleri bilen bir insan (Şahin, 1984: 57).

Akis, dinamik bir habercilik anlayışıyla, renkli bir uslübu haber dergiciliğine kazandırmış, kendisinden sonra yayımlanan haber dergilerine model olmuştur. Akis'in yanı sıra 1980 öncesi yayın yapan haber dergisi olarak Devir ve Kim dergileri anılabilir. Devir Dergisi, Altemur Kılıç tarafından, bankacı Kazım Taşkent ve TÜSiAD'ın destekleriyle, Time ve Newsweek dergileri örnek alınarak çıkartılmış, ancak yayın hayatı uzun süreli olmamıştır. Haluk Şahin bunun nedenini, derginin Ankara ayağını zayıf bırakmasının olarak açıklamaktadır (Şahin, 1984: 61).

Özcan Ergüder, Ali İhsan Göğüş, Sefa Balcıoğlu ve Orhan Birgit'in 3'er bin lira sermaye koyarak kurduğu Kim dergisi, 30 Mayıs 1958'de yayınlanmaya başlamış, DP tarafından bir ay süreyle kapatılmış, 1968'e kadar yayınlanmayı sürdürmüştür. Kim'in yazar kadrosunu, Emil Galip Sandalcı, Fikret Otyam, Refik Erduran ve Halit Refiğ, Tarık Dursun K., İlhami Soysal gibi muhalif isimler oluşturmuştur. Time dergisinin Türkiye muhabirliğini de yapan gazeteci Mehmet Ali Kışlalı'nın 1971 yılında yayımlamaya başladığı Yankı dergisi ise, daha popüler bir habercilik anlayışı ile cinsel içeriği kaynaştıran bir dergi olmuştur (Eryılmaz, 2002: 211).

12 Mart darbesi ile birlikte oluşan yeni siyasal iklime destek veren Yankı dergisi, uzun bir süre haber dergiciliği alanında tek başına var olmuştur. Bu durum 12 Mart'a açıkça muhalefet edeceğini duyuran Ortam dergisinin çıkmasıyla değişmiştir. Kadrosunda Osman Arolat, Aydın Engin, Mümtaz Sosyal, Muammer Aksoy, Ali Sirmen gibi isimleri barındıran Ortam, baskılar nedeniyle sadece 8 ay ayakta kalabilmiştir. Sonrasında çıkartılan Yeni Ortam dergisi ise kısa bir süre sonra günlük gazete formatına geçmiştir (Şahin, 1984: 66).

Bu dönem yayımlanan haber dergilerine bakıldığında, politika haberlerinin ön planda olduğu, bunun yanında moda, sanat, sinema, spor gibi başlıkların da sunulduğu görülmektedir. Iktidar yanlısı yayın yapan kişilere (örneğin Necip Fazıl'ın Büyük Doğu Dergisi) örtülü ödenekten para aktarılırken muhalif bir dergi olan Kim'in 1958 yılında kağıdının kesilmesi, birçok yayının ilan gelirlerinden yararlandırılmaması gibi örnekler (Topuz, 2014: 206), Demokrat Parti döneminde sansür politikalarının ekonomik boyutuna işaret etmektedir. Bunun yanı sıra, 1980 öncesi dergicilik genel olarak değerlendirildiğinde, haber dergisi sayısının, diğer türden dergilere oranla çok düşük olduğu görülmektedir. 1923 ile 1963 yıllar arasında bu oran ortalama yüzde 4'tür (Kocabaşoğlu, 1984: 10). 


\section{0-90'larda Haber Dergiciliği ve Express'in Kökleri}

1980 yılında açıklanan 24 Ocak Kararları ve 12 Eylül'de yapılan askeri darbe, toplumsal yaşamın bütün alanlarını olduğu gibi basını da ciddi bir şekilde etkilemiştir. Basın ve ifade özgürlüğünü muğlak ve anlaşıması güç ifadelerle kısıtlamaya zemin hazırlayan, ihlalleri meşrulaştıran 1982 Anayasası, Olağanüstü Hal Kanunu ve yeni Basın Kanunu'nda öngörülen ağır yaptırımlar (1983) basın üzerindeki siyasi baskıları arttırmıştır. Sözde liberal politikaların uygulandığı Turgut Özal döneminde dahi pek çok gazeteci öldürülüp tutuklanırken, en ağır darbeyi sosyalist çizgide, bağımsız veya sol örgütler çevresinde faaliyet gösteren dergiler almıştır. Doksanlı yıllarda da bu tablo değişmemiş, 1991 yılında çıkarılan Terörle Mücadele Kanunu kapsamında başta 2000'e Doğru, Nokta, Yüzyıl olmak üzere, pek çok sol-sosyalist dergi defalarca kapatılmış, toplatılmış veya yazarları çeşitli cezalara çarptııılmıştır (Topuz, 2014:162-163).

Diğer yandan kağıt sübvansiyonlarının kaldırılması ve basın sektörünün kuralsızlaştırılması gibi nedenlerle, 1980'lerin ortasından itibaren gazeteci patron dönemi sona ermiş, basın kuruluşları hızlı bir şekilde başka alanlarda yatıım yapan holding patronlarının eline geçmeye başlamıştır. Bu süreçte küçük basın kuruluşları ağırlığını kaybederken, özel televizyon kanallarının da kurulduğu 90'lı yıllar boyunca tüm medya sektörü gibi dergi yayıncılığı da çeşitli büyük holdinglerin baskın olduğu bir sektör haline gelmiştir (Bulunmaz, 2011: 237). Tekelleşme eğilimlerinin en önemli sonuçlarından birisi, gazetecilerin sendikasızlaştırılması ve medya sektöründe güvencesiz çalışma koşullarının yaygınlaşması olmuştur. Haber ve içeriğin magazinleştirilmesi ve gazetelerin git gide siyasi gündemden uzaklaşarak, ekonomiye, bireye ve tüketime odaklanan bir yaşam tarzı haberciliğine meyletmesi ise basın kuruluşları üzerindeki siyasi baskı ve tekelleşmenin diğer bir etkisi olarak görülebilir (Özgen, 2011: 470).

Haberin magazinleştiği bu dönemde, gazetelerin sun(a)madığı ciddi haberleri sunma cesaretini gösteren haber dergileri ön plana çıkmıştır. Bu dergilerin en çok ses getireni Nokta'ysa da, Yeni Gündem ve 2000'e Doğru dergileri de, yayınladıkları dosyalar ve özel haberlerle, kendilerinden söz ettirmişlerdir. 1984 yılında yayın hayatına başlayan Yeni Gündem, Murat Belge yönetiminde İletişim Yayınları tarafından kurulmuştur. Illk iki sene 15 günlük, 1986'dan itibaren ise haftalık olarak yayınlanan Yeni Gündem'in kadrosunu çoğunlukla Birikim dergisi çevresi oluşturmuştur. Cengiz Turhan, Ümit Kıvanç, Can Kozanoğlu, Tanıl Bora ve Tuğrul Eryılmaz dergiyi çıkaranlar isimler arasındadır. Ancak derginin Birikim'den farkı, çıkış yazısında da vurgulandığı gibi, teorik bir sol yayın olmaktan ziyade habercilik iddiasını taşımasıdır (Oktay, 2009: 37). Dört sene boyunca güncel siyasi konuları ve olayları işleyen dergi 1988 yılında kapanmıştır. Eryılmaz, Yeni Gündem'in siyasi çizgisini ve okur kitlesini şöyle açıklamaktadır: 
Nokta siyah Türkleri de fazla inmal etmeden liberal ve solda beyaz Türkler için çıkarken, Yeni Gündem beyaz Türkleri de çok inmal etmeden (Ayşe Silivri'nin Vakko'dan reklam koparma başarısı hâlâ bir efsane olarak anlatılır) daha az beyaz ve fakat daha solda Türkler için çıkıyordu (Eryılmaz, 2002: 213)

Dönemin bir diğer önemli dergisi de 2000'e Doğru'dur. Doğu Perinçek'in başyazarı ve genel yayın yönetmeni olduğu haftalık dergi, özellikle derin devlet ve Güneydoğu Bölgesi'ni konu alan haberleriyle gündem yaratmış, "Abdullah Öcalan röportajı" gibi o dönem çok riskli sayılabilecek metinler yayımlamıştır. Bu haberleri nedeniyle devlet baskısına maruz kalan derginin bazı muhabirlerinin "derin" güçler tarafından katledildiği iddia edilmektedir (Akdağ, 2004). Ayrıca 2000 'e Doğru, yayın politikası nedeniyle 1990'a kadar 22 kez toplatılmıştır. Turan Dursun ve Cemal Süreya gibi aydınların yazarlık yaptığı dergi, 21 Mart 1993'te günlük Aydınık gazetesinin yayımlanma kararı nedeniyle kapatılmıştır.

Bu dönemde Ercan Arıklı yönetimindeki Nokta dergisi muhalif yayın çizgisiyle önemli habercilik başarılarına imza atmıştır (Gönenç, 2007). 12 Eylül döneminin politik ruhuna aykırı kapakları ve konuları işleme biçimiyle Nokta, iSKi Skandalı'ndan işkenceci polislere kadar birçok konuyu Türkiye kamuoyunun gündemine oturtmuş, yayımlandığı dönemde kendinden sıkça söz ettirmiştir. Bu özellikleriyle Nokta, Batılı anlamda haber dergiciliğinin Türkiye'deki en önemli temsilcisi olmayı başarmıştır. Bu dönem Nokta'yı yayımlayarak büyük bir risk alan Ercan Arıklı, derginin maliyetini, sahibi olduğu ve popüler yayın yapan Erkekçe ve Kadınca dergileriyle karşılamaya çalışmıştır (Akdağ, 2004).

Nokta'nın kurucu ekibi, Arıkı'nın davetini kabul eden Ankara SBF Basın Yayın Yüksekokulu'ndan bir grup asistandır. 12 Eylül yönetiminin baskıları nedeniyle üniversitelerde başlayan istifalar, aralarında Tuğrul Eryılmaz, Uygur Kocabaşoğlu ve Yazgülü Aldoğan'ın da olduğu asistanları sektöre girmeye teşvik etmiş, Nokta dergisi bu ekip tarafından hazırlanmıştır (Eryılmaz, 2002: 211). Kısa sürede başarı yakalayan, kadrosunu yeni isimlerle genişleten dergi, Ercan Arıkı'nın 1987 yılında günlük Söz gazetesini kurmasıyla birlikte sıkıntıı bir döneme girmiştir. Tuğrul Eryılmaz'a göre Arıklı́nın, sermayesini büyütme arzusu, Nokta'nın sahip çıktığı habercilik anlayışını büyük ölçüde zedelemiş ve git gide derginin içeriğine müdahale edilen bir döneme girilmiştir (Eryılmaz, 2002: 212).

Nokta'nın yakaladığı başarının ardından, Hürriyet Dergi Grubu 1987 yılında Nokta'ya rakip olarak kuşe kağıda basılı ve tümüyle renkli olarak Tempo dergisini yayınlamaya başlamıştır. Ardından Bilgin Grubu'na ${ }^{2}$ ait Bir Numara Yayıncılık'ın Aktüel'i gelmiş (1989); dergi, rakiplerinden farklı olarak boyutunu enden boydan iki parmak büyüterek satışlarını yükseltmiştir. Nokta'nın da içinde bulunduğu

2 Dinç Bilgin 2000'lerin başına kadar medya alanında büyük yatıımları olan bir holding patronuydu. Sahip olduğu kuruluşlar arasında Show TV, ATV, Kanal 6 televizyonları, Yeni Asır, Sabah, Takvim, Fotomaç ve Bugün gazeteleri de bulunmaktaydı. Ancak Show TV'yi 1997'de Erol Aksoy'a, diğer kuruluşları ise 2002 yılında Ciner Grubuna satarak medya alanından büyük oranda çekilmiştir. 
Gelişim Yayınları ise 1989 yılında Günaydın, Tan ve Güneş gazetelerinin yanı sıra Veb Ofset'i elinde bulunduran Asil Nadir'e satılmıştır. Satışın ardından Ercan Arıklı, Sabah gazetesi sahibi Dinç Bilgin'le Bir Numara Yayıncılığı kurmuştur. Nokta, Asil Nadir'in medya sektöründen çekilmesiyle önce Bülent Şemiler'e ait Interpress Basın ve Yayıncılık A.Ş'ye geçmiş ardından 1994 yılında Masum Türker tarafından satın alınmıştır. Daha sonradan da pek çok defa el değiştiren Nokta dergisi, 2006 yılında yeni bir içerikle gündem oluşturmayı başarmış ve 2007 yılının Nisan ayında Darbe ve Andıç dosyalarını yayımladıktan sonra polis baskınına uğramış ve kapanma kararı almıştır (Suiçmez, 2009: 86-88).

Nadir Grubu tarafından satın alınmadan önce, Nokta, şaibeli iş ilişkileri olan ve sansasyonel yaşantısı nedeniyle sürekli haberlere konu olan Asil Nadir'i kapak konusu yapmıştır (Adaklı, 2006: 178). Eleştirel bir biçimde ve derinlemesine hazırlanan bu haber Nadir'i oldukça sinirlendirmiş, sonrasında ise dergiyi satın almıştır. Nokta'nın Asil Nadir'e satılmasının bu hikayesi, dönemin, meslek ilkelerini piyasa kurallarıyla yıkıp geçen neo-liberal taarruzu hakkında fikir sahibi olmamızı sağlayacak öğreticiliktedir.

\section{Ana Akımdan Kopuş ve Alternatif Medya Olarak Express}

Dergi yayıncılığında 1980'li yıllarda başlayan yoğunlaşma hareketleri, 1990'lı yıllarla beraber daha da artmıştır. 90'larla birlikte, "dergi yayıncılığının karlı bir alana dönüştüğünü gören ve büyümeyi hedefleyen gruplar, bu alana yatırım yapmaya başlamıştır (Sözeri, 2007: 112). Yine bu dönemde dergiler sayıca artmakla beraber, tematik hale gelmiş, sabit bir okur kitlesi oluşturmaya başlamış ve kurumsallaşma yoluna giderek uzun ömürlü olmuştur (Bulunmaz, 2009: 71).

İleride Express dergisinde buluşacak olan gazeteciler de, 91-92 yıllarında Nokta'dan ayrılarak yoğunlaşma ve el değiştirme furyası nedeniyle çeşitli dergi ve gazetelere dağılmışlardır. Express dergisinden Yücel Göktürk Nokta'yı şöyle anlatmaktadır: "Dönem farklıydı, gerçekten de haberin hakkı verilirdi. Tam bir haber dergisiydi Nokta. Sahibinin de yegane işi buydu zaten, kendisi de ansiklopedicilikten geliyordu" (Göktürk, 2013).

Nokta macerasının sona ermesinden sonra, ileride Express dergisini kuracak olan gazetecilerden bazılarının çalıştığı Milliyet Grubu'na bağlı Ekonomik Panaroma (EP) dergisinden üç gazeteci, derginin "Uzan Ailesi Nereden Koşuyor" başııkı haberinin yarattığı kriz sonrası işten atılır. Derginin Uzan haberinin olduğu sayısının, Doğan tarafından piyasadan toplatılması ve Uzan'a barış eli uzatmak için üç gazetecinin işten atılması üzerine EP'de çalışmakta olan bütün gazeteciler istifa eder. 90'ların başında gazeteciler ellerindeki sosyal ve ekonomik haklarını henüz tam olarak kaybetmediği için, istifa eden bütün gazeteciler 212 sayılı kanunun kendilerine tanıdığı hakka 3 istinaden kıdem tazminatlarını alır.

3212 sayılı kanunun gazetecilere tanıdığı "mesleki tepki hakkı" (clause concience), yayın organının 
Nokta'da başlayan birliktelik, sonrasında çeşitli dergi ve gazetelere dağılarak sekteye uğrasa da 1994 yılının Ocak ayında Express dergisinin çıkmasıyla sürdürülür. Express'in ilk sermayesi, EP'de yaşanan işten atma ve istifalar sonucu elde edilen tazminatlardan karşılanır (Göktürk, 2013). Derginin çıkışında yer alan isimler arasında Can Kozanoğlu, Aydın Demirer, Kemal Can, Sungu Çapan, Ümit Bayazoğlu, Erdir Zat, Siren İdemen, Ragıp Duran, Yücel Göktürk yer almıştır. Göktürk, Express'i kurma amaçlarını şöyle anlatmaktadır: "Milliyet Grubu resmen kendi dergisini toplattı ve bizim üç arkadaşımızı işten attı, biz de bunun üzerine istifa ettik. Orada biz işte noktayı koyduk. O toplu istifa edenlerden bir grup bu işi kendi kendimize yapalım, bu iş sermaye grubuyla olmuyor dedik" (Göktürk, 2013).

"Sahibinin sesi değil, kendi sesi" sloganıyla çıkartılmaya başlanan Express dergisi, 1997 yılına kadar haftalık olara k yayımlanmış, aynı yıl mali ve idari yetersizlikler nedeniyle kapanmak zorunda kalmıştır. Göktürk söz konusu süreci şöyle aktarmaktadır: "Biz haftalık dergi yapabileceğimizi sandık. Ancak haftalık dergi yapmak çok zor. Biz üç sene dayanabildik, sonra yıldık ve bıraktık. Artık haftalık yapamıyoruz dedik, borçlanıyorduk, gelir gideri karşılamıyordu" (Göktürk, 2013).

Dergi ekibi, Express dergisinin yayınına son vermelerinin ardından Roll ismiyle bir müzik dergisi yayımlamaya başlar. Aylık olarak çıkartılan Roll, kısa süre içerisinde ciddi bir etki yaratmış, (alternatif bir yayına göre) geniş bir okuyucu kitlesine ulaşmıştır. 2001 yılında Express aylık olarak yeniden yayına başlar. Express adıyla, kaldıkları yerden devam etmek istemediklerini belirten Göktürk, dönemin "moda" öneklerinden "Post"u da isimlerine ekleyerek yeni bir dergi çıkarmaya başladıklarını söylemektedir. Aylık Post-Express boyutu ve tasarımıyla da Express'ten farklılaşmaktadır. Bu dönem gerek eski Express müdavimleri, gerekse dergiyle yeni tanışan gençler tarafından ilgiyle karşılanan PostExpress'te bir süre sonra yine bir isim sorunu baş gösterir: "Sol camianın 'post' lafından hoşlanmaması, gazete bayilerinde derginin isminin Posta gazetesiyle karıştırılmasından dolayı sıkıntılarla karşılaşmamız nedeniyle derginin ismini yeniden Express yaptık. Ama hala Post-Express diyenler var. Post'tan da tam anlamılla kurtulamadık" (Göktürk, 2013).

Medyanın, gazetecilikle bir bağı olmayan holding patronları tarafından satın alındığı, reklam ve promosyon savaşları arasında haberciliğin niteliksizleştiği ve basın emekçilerinin güçsüzleştirildiği bir dönemde çıkan Express bağımsız ve sermaye gruplarından azade olmayı çok önemsemekte ${ }^{4}$, ancak bu bağımsızlığı

siyasi çizgisinde meydana gelen bir değişiklik sonrası, gazetecilere tazminatlarını alarak işten ayrılma olanağı sağlamaktadır.

4 Express'in, 1994 yılında ilk sayısının çıkışından önce hazırladığı afişte şunlar yazmaktadır: "Patronu yok, holdingi yok, şefi yok, partisi yok, tarikatı yok! Illkesi var, haysiyeti var, meslek ahlakı var! Sırtında yumurta küfesi yok; sorumluluk duygusu var! Kimseye diyeti yok, özgürlüğü var! Sahibinin sesi değil, kendi sesi..." 
apolitiklik olarak algılamadığını özellikle vurgulamaktadır. Express'in 112. sayısının giriş yazısında bağımsızlık anlayışı şu şekilde açıklanmaktadır:

"Express her bakımdan bağımsız bir yayın. Hiçbir sermaye grubu veya türüyle, sivil toplum kuruluşuyla, fon mekanizmasıyla bağlantısı olmadığı gibi, hiçbir partiyle, örgütle, siyasal oluşumla da ilişkisi yok. Yüzde yüz bağımsız ve aynı zamanda yüzde yüz angaje. Neye angaje olduğumuzu Ocak 1994'te ilk sayımızda ilan etmiştik, 16 yıldır o söze bağlıyız: Savaşsız ve sömürüsüz, efendisiz ve tahakkümsüz bir dünya idealine. Bu angajman Express'in varoluş sebebi." (Express, 2010b)

Halkların Demokratik Partisi Milletvekili Sırrı Süreyya Önder'in değerlendirmesi de Express dergisinin bu yönüne dikkat çekmektedir:

"Express mevcut sol siyasal yapılardan herhangi birinin ya da herhangi birkaçının bir kombinasyonu olabilir mi? Olamaz. X sol siyaset hareket 'Express bizim yayın organımızdır' diyemez. Açık söyleyeyim, hayatın o güne kadar ihmal ettiğimiz, bize önemsizmiş gibi gelen mikro alanlarının ne kadar da önemli olduğunu, gelecekte ne hal alacağını ortaya çıkarmak gibi bir işlevi oldu Express'in; kendi adıma, tüm sol siyasal bilinçlenmem kadar tek başına bir işlev gördü. Hakim bakışın görmediği yerden yaklaşma çabası, o deyimi kullanmak istemiyorum ama, ufuk açıcı." (Önder, 2013)

Express dergisinin odağında, 2002 yılından beri AKP iktidarının kurmaya çalıştığı yeni neoliberal-İslamcı hegemonya ve sözde ona muhalefet edermiş gibi görünen, aslında bu hegemonyanın dayandığı temelleri sağlamlaştırmaktan öteye gitmeyen ulusalcılık ve sol-liberalizm gibi ideolojiler vardı. Ragıp Duran, Express'in 2002 sonrası mevcut Türkiye siyaseti içerisindeki tutumunu şu sözlerle aktarmaktadır: “Express, AKP iktidarına karşı her alanda sıkı muhalefet yaparken, kadim rejimin askerperver yaklaşımına ya da liberallerin gevşek tutumlarına prim vermedi. Iktidar ile muhalefet arasında seçimini her zaman muhalefetten yana yapmış olsa da, muhalefette bulunan dogmatik, Kemalist ya da milliyetçi odaklardan uzak durmayı hiç unutmadı" (Duran, 2015).

Express, büyük politik tartışmaları konu edinmesinin yanında, “özel olan politiktir" mottosuyla, ekonomik, toplumsal ve kültürel dünya ile de aynı oranda ilgilenmiştir (Duran, 2015). Dergi, özellikle AKP döneminde artan özel yaşama müdahale politikalarını da eleştirel bir dille gündemleştirmiştir. Örneğin, sigara yasağının kapsamının genişletildiği 2009 yılında çıkan 96. sayısında, sigara yasağına açık olarak tavır almış, bu yasağı "neo-liberal faşizm" olarak nitelemiş ve John Berger ile Joe Jackson'ın sigara yasakları konusundaki eleştirel görüşlerini aktarmıştır (Express, 2009).

Derginin sosyalist sol ile ilişkisi de önemli bir konudur. Express sol değerlere ve düşünce sistematiğine angaje bir yayın anlayışına sahip olduğunu en başından beri açıkça ifade etmekle birlikte, gerek dili, gerek organizasyon yapısı, gerekse de habere ve içeriğe bakış açısı hasebiyle herhangi bir siyasal örgütten 
bizatihi uzak bir yayındır. Duran'ın ifadesiyle "yönlendirmeye, başkanlık/liderlik/ önderlik etmeye değil anlatmaya, bilgilendirmeye adanmış bir yayın politikası benimsemişti Express. Express'in konu olarak kapsama alanı da diğer sol ya da örgüt yayınlarından fersah fersah genişti. Sol adına siyaset yapan sağcıların pek hoşlanmadığı bir dergiydi Express" (Duran, 2015).

Derginin çıkarken kullandığı "sahibinin sesi değil, kendi sesi" sloganı bir süre sonra terk edilmiş, yerine, Mano Solo'nun bir şarkısına gönderme olarak, "Enternasyonal Şalala" sloganı, logo altında, kullanılmaya başlanmıştır. Aslında, bu slogan ile birlikte derginin yayın çizgisine ve diline genel olarak bakıldığında, Express'in doktriner bir dil yerine, mizah ve şiirle güçlendirilmiş, "şenlikli muhalefet" olarak nitelendirebileceğimiz, coşkulu bir dili kullandığını söyleyebiliriz. Ancak Express, "Enternasyonal Şalala" ile sol muhalefetin bir dilinin olmasının yeterli olmayacağını, onun bir "ses"e de ihtiyacı olduğunu vurgulamaktadır:

\begin{abstract}
"Uzun zamandır solun yeni bir dil bulması, kurması tartışılıyor. Ama nasıl bir sesi olması gerektiğine dair somut bir şey pek söylenmiyor. Bizim önerimiz malum, 'Enternasyonal Şalala'. Mano Solo'dan Marcos'a, John Berger'dan Jacques Brel'e, Mos Def'ten Mahsuni'ye, Dylan'dan Strummer'a, Hendrix'ten Kaygusuz'a uzanan o ses, o his..." (Express, 2010a).
\end{abstract}

Express'in, her iki döneminde de bazı konuları ısrarla işlediği görülmektedir. Kentsel dönüşüm, iş̧̧i mücadeleleri, ekolojik mücadeleler, Kürt sorunu, göçmen sorunları ve mücadelesi, iş cinayetleri dergi tarafından en sık işlenen konulardır. Express, Tekel Direnişi, Tuzla tersanelerindeki iş cinayetleri, Gülsuyu/Gülensu mahallerine yönelik kentsel dönüşüm hamleleri gibi tekil örnekleri birkaç sayı boyunca ayrıntılı bir şekilde okuyucularına sunarken; bugüne kadar "Kürt Sorunu", "Hrant Dink", "Neo-Islam", "Gezi Direnişi" ve "Yeni Siyaset" başlıklarıyla özel sayılar hazırlamıştır.

Express'in üzerinde durmakta ısrar ettiği bu konular, devlet baskısını da beraberinde getirir. Derginin Eylül 2009 sayısında Irfan Aktan imzasıyla yayımlanan "Bölgede ve Kandil'de Hava Durumu / Mücadele Olmazsa Çözüm Olmaz" yazısı nedeniyle yazar ve sorumlu yazı işleri müdürüne açılan davada, yazar İrfan Aktan "terör örgütü propagandası yapmak" suçundan 1 yıl 3 ay hapis cezasına, sorumlu müdür Merve Erol ise 16 bin TL'lik para cezasına mahkum edilir (Önderoğlu, 2010).

Express'te, (zaman içinde bir kısmı kaldırılan) çeşitli disiplin başlıkları bulunmaktadır. Radyo Express başlığında uluslararası haberler ve çeviriler yer almakta, Müzik Dolabı'nda yeni çıkan albümler değerlendirilmekte, Kıraat ve Dumanı Üstünde başlıklarında yeni çıkan kitaplar tanıtılmakta ve kısa kitap değerlendirmeleri yazılmakta, Radyo Brecht'te yeni medya ve bilişim teknolojileriyle ilgili güncel gelişmeler aktarılmakta, Ağır Çekim başlığında sinema sektöründen haberler yer almakta, bağımsız yapımlar tanıtılmakta, Meşin 
Yuvarlak'ta futbol yazıları ve haberleri sunulmakta ve Umut Mekanlari'nda kentsel gündeme ve mücadeleye dair yazılar yayınlanmaktadır.

Express'in yayın çizgisine bakıldığında, yeni toplumsal hareketlerin bu çizgide önemli bir yer kapladığı görülmektedir. Express'in, geleneksel siyasetten dışlanan birçok konuyu gündeme getiren, hitap ettiği kamuoyu nezdinde görünür ve tartışılabilir kılan, yeni toplumsal hareketlerin ve hak mücadelelerinin (Yıldırım, 2013: 81) bir arada ve sıklıkla konuşabildiği bir alan olduğu rahatlıkla söylenebilir. Feministler, ekolojistler, LGBTi aktivistleri, vicdani red aktivistleri ve göçmen dayanışma hareketi mensupları, derginin sözlerini sıklıkla aktardığı kesimlerden yalnızca bazılarıdır. Göktürk, Express'in habercilik pratiğini bir söz aktarımı olarak tanımlıyor: "Bizim habercilik pratiğimiz 'eyleyen özneler'i konuşturmak üzerine. Mesela Kazova İşçileri, bir şey yapmışlar. Bizim burada yapacağımız gidip onlara o şeyi anlattırmak. Mesele özneyi konuşturmak, bizim onun yerine konuşmamız değil" (Göktürk, 2013).

Merve Erol ise Express'teki özneleri konuşturma eğiliminin müzik dergisi Roll'dan geldiğini ifade etmektedir:

Express, özellikle söyleşi ağırlıklı olan Roll'un da etkisiyle, ikinci (aylık) döneminde
olayların faillerine daha fazla mikrofon tutmaya, söyleşi ve yazı dengesini daha iyi
kurmaya başlamıştı. Daha önceki müzik dergilerinin aksine Roll, sözü asıl faile,
müzisyenin kendisine bırakmayı arzuluyordu. Bu anlamda Express de, dışarıdan
ahkâm kesme riskini en aza indirmeye çalışarak asıl özneleri dinlemeye çalıştı."

Bu bağlamda üzerinde durulması gereken diğer bir önemli nokta ise, gelen yazıların her daim "editoryal bir mercekten veya kurgudan geçerek" yayımlandığıdır. Ancak buradaki gayenin içeriğin kontrolünden çok okuma zevkinin yükseltilmesi olduğu ifade edilmektedir (Erol, 2014).

Özneleri konuşturma eğiliminin en doğrudan ifadesi derginin 19. yılına ve 136. sayısına denk gelen Gezi Özel Sayısı'dır. Bu sayısında Express, direnişin doğmasını sağlayan mücadelelerin örgütleyicilerinden, direniş içerisinde görevler almış yapılara, LGBTi aktivistlerinden, taraftar gruplarına kadar örgütlü veya örgütsüz, farklı politik öznelerin sözünü taşımıştır. Tüm bu politik özneler, Express mecrası üzerinden, kendi kimlik ve aidiyetlerinin yansıması olan öznel Gezi deneyimlerini, yine kendi ifadeleriyle aktarma olanağına kavuşmuştur. Erol, Gezi Özel Sayısı'nı hazırlama sürecini şöyle ifade etmektedir:

Tabii Gezi'ye katılan herkesi, bütün örgütlü kesimleri yansıttığımızı söylemek mümkün değil, ama parka ilk gidenlerden ilk çadır kuranlara, barikatlarda duranlardan Gezi'ye uzanan çok çeşitli protestolarda (mesela Emek sineması) ısrar edenlere sözü bırakmaya, duvarlarda, Twitter gibi platformlarda üretilen sözü, pankartları, yazılamaları belgelemeye, müzikten sinemaya, çağdaş sanata, olaya farklı gözlüklerden bakmaya çalıştık. Görsellerde çoğu dostumuz olan geniş bir fotoğrafçı ağına başvurduk (Erol, 2015). 
Aynı günlerde, başka bir Gezi Özel Sayısı hazırlayan ana akım haber dergisi Tempo dergisinin, bu sayıda direnişin içerisindeki örgütlü özneleri geri plana itip, örgütsüzlügü bütün direnişi kapsayan bir özellik olarak sunan, genel olarak direnişi "yaşam tarzı savunuculuğu" noktasına hapsedip apolotikleştiren ve onu sistem için kabul edilebilir ve pazarlanabilir bir ürün veya gösteri haline getiren üslubu göz önünde bulundurulduğunda, Express'in dönemin ana akım haber dergiciliği mantığından ne ölçüde farklılaştığını daha iyi anlamak mümkündür.

\section{Express'in Mali ve İdari Yapısı}

Express dergisinin ekonomik girdisini sadece yayınevlerinden gelen reklamlar ve dağıtımcı firma ile kitapçılardan gelen dergi satışları oluştururken, gider kalemleri ise matbaa ve büro masraflarıdır. Yukarıda aktardığımız Tempo'nun reklam tarifesine karşıık, Express'in kapak içleri reklam bedeli bin TL civarındadır. Dergiye emek verenlerin hiçbiri düzenli bir maaşa sahip değildir. Reklam ve satıştan elde edilen gelir, matbaa ve büro masrafları aradan çıkarıldıktan sonra, dergi çalışanları arasında eşit bir şekilde bölüştürülmektedir. Özel durumlarda ise dostluk ve dayanışmanın devreye girdiği dergide; örneğin, bir dergi çalışanının 'yan iş' (çeviri, redaktörlük gibi) bulması durumunda payına düşen gelire ihtiyacı olmadığını söyleyerek, o paranın diğer çalışanlara yine eşit şekilde bölüşümü mümkün kılınmaktadır:

Paranın eşit bölüşümü noktasında itirazlar da oluyordu. Ancak bu itirazlar dergiye daha az emek ve beceri koyanlardan geliyordu. Bu bir sosyalizm sorunu. Bizim bu aşamada yapmamız gereken bu. Kaç kişiyiz; kaç lira var 700 lira var, kişi başı 100 lira. Bizim durumumuz budur. Tüm hesap ve kitabın şeffaf olması çok önemli (Göktürk, 2013).

Derginin satış rakamı üç bin civarındadır. Dolayısıyla dergi özellikle ilk dönemlerinde çok sefer zarar etmiş ve borçlu duruma düşmüştür.

Express'in künyesinde ise, yasal olarak zorunlu alanlar (imtiyaz sahibi ve sorumlu yazı işleri müdürü) dışında herhangi bir idari görev belirtilmemekte, derginin asıl kadrosuyla birlikte, ilgili sayıya bir şekilde katkı sunmuş herkes "katkıda bulunanlar" başlığı altında sıralanmaktadır. Dergi içeriğinin belirlenmesinde hiyerarşik bir işleyiş izlenmemekte, herkesin katkı sunup, etki edebileceği bir yapı benimsenmektedir. Dergiye katkı sunan muhabir ve yazarlara telif verilmemekte, içerik üretimi gönüllülük esasına binaen gerçekleştirilmektedir. Dergide düzenli haber toplantıları yapılmamakta, içerik çeşitli sosyal ortamlarda yapılan görüşmeler sonucunda ve e-posta grubunda belirlenmektedir. Göktürk, Express'in çalışma tarzı ile ilgili şunları söylemektedir:

"Biz bu işin dışında da bir aradayız; beraber top oynuyoruz, sinemaya gidiyoruz. Tüm bu meseleleri de bir aradayken konuşuyoruz. Hiçbir şekilde haber toplantısı yapmıyoruz. E-posta grubumuz var ve oradan haberleşiyoruz. Bu işin merkezinde dostluk duruyor. İsin temeli o. Profesyonel bir ilişkiden çok dostluk duruyor ve 
bu halen devam eden bir dostluk. Nokta'dan beridir beraberiz, 20 seneden bile önceye dayanıyor ilişkilerimiz (Göktürk, 2013).

Ancak genel hatlarıyla bakıldığında bizzat dergi mutfağında olan, dergiye düzenli içerik ve katkı sunan bir ekibin yanında, bu çekirdek ekibin çevresinde yer alan ve dergiye daha düzensiz katkı sunan bir grubun bulunduğunu söylemek mümkündür. Hatta dergi, yurttaş gazeteciliği olarak anılabilecek okur katkısından da beslenmiştir (Erol, 2015). Dolayısıyla Express'in organizasyon yapısını merkezden dışarı doğru esnekleşen ve dergiye bağlıı̆̆ı azalan çekirdek ekip, destek ekip ve okuyucu-yurttaş şeklindeki üçlü bir kategori olarak ele alabiliriz.

Derginin kurumsal bir yapıya sahip olmadığını ve profesyonel bir iş bölümünün bulunmadığını söylemek mümkündür. Bu durum Express'i özellikle sektöre yeni giren genç gazeteciler için, haberin üretiminden yayımına, hatta dağıtımına kadar pek çok süreci öğrenebilecekleri bir okul durumuna da getirmektedir. Tabii bunda dergi içerisindeki hiyerarşik olmayan, dostane ve geliştirici ilişki biçiminin de unutmamak gerekir. Marmara Üniversitesi İletişim Fakültesi öğrencisiyken Express ekibine dahil olan Erol'un anlatımı durumu özetlemektedir:

Bu gazeteci çevresiyle biraz da tesadüfler sonucu karşılaştık, hayatımdaki ilk söyleşileri, izlenim ve yorum yazılarını onların yönlendirmesiyle, teklifiyle, tavsiyesiyle yazdım. Çokça tökezledim, ama her seferinde desteklendim, bir süre sonra da derginin temposu okulun ritmine baskın çıktı. O dönemin Koordinasyon oluşumundan daha pek çok genç insan Express'e bu şekilde bağlanmıştı (bir süre sonra bir Kampüs sayfası da oluşmuştu). Diyebilirim ki hakiki basın-yayın okulu benim için üniversiteden de fazla Express ve sonraki haftalık futbol dergisi Meşin Yuvarlak, aylık müzik dergisi Roll, Bir+Bir oldu... Kendi adıma, muhabirlikten musahhihliğe, matbaa kontrolünden dağıtıma, ucundan da olsa mizanpaja kadar derginin her şeyine bulaşmışımdır, diğer arkadaşlarım gibi (Erol, 2015).

\section{Sonuç ve Değerlendirme}

Hiçbir sermaye grubuna ve siyasi oluşuma bağlı olmayan Express dergisinin, 'alternatif yayıncılık' çizgisinde durduğu açıkça görülmektedir. Bu çalışmada mali yapısı, idari yapısı ve üretim süreci açısından ele alınan Express'in, kendisini yayınevi reklamları, dergi satışları ve abonelik sistemiyle idame ettirdiği ve kar amacı gütmediği görülmektedir. İdari işleyişin, hiyerarşik bir iş ilişkisi ile değil, tersine 'dostluk' ve gönüllülük temelli yatay bir ilişki dolayımıyla kurulduğu açığa çıkmaktadır. Öte yandan yayın, belirli bir mekâna bağlı kalmadan çalışmakta, sabit bir çekirdek kadroya sahip olmanın yanında dergiye katkı sunan isimler her sayıda farklılık göstermekte, hatta okuyucu da bizzat dergiye katkıda bulunabilmektedir. Dergi örgütlenmesinin esnekliği ve gayri merkezi oluşu önemli bir husus olarak göze çarpmakta, bu ise yönetim anlayışının katııma açık ve şeffaf biçimde işlemesini sağlamaktadır. 
İçerik üretiminde ise reklam gelirlerini artıımanın bir yolu olarak magazinel ve sansasyonel yayıncıı anlayışını odağa alan ana akım haber dergilerinin aksine, Express, 'eyleyen özne' olarak tanımladığı kesimlere söz hakkı tanımakta ve onların eylemlerini gündemleştirerek ana akımdaki çarpık temsil krizine karşı alternatif bir yayın olarak karşımıza çıkmaktadır. Dergi siyasi arenada var olan neoliberal İslamcl, sol liberal veya ulusalcı-milliyetçi hegemonya projelerine yönelik muhalif tutum takınmasının yanı sıra bu perspektiflerin görünmez kıldığı kimi konuları gündem haline getirebilmektedir. Hatta Express her ne kadar sol-sosyalist anlayışı merkeze alarak yayın yapsa da, bu anlayışın Türkiye'deki gelenekselleşmiş dil ve muhalefet kalıplarını da zorlayan bir üslup ve içeriği tercih ettiği söylenebilir.

Liberal demokrasinin dayandığı temsil sistemi, bugün, modern demokrasinin meşruiyet krizinin de temel nedenidir. Çünkü temsili demokraside, yurttaşlar yasaların yaratıcısı olmaktan çıkarılmıştır. Burada halkın iradesi seçilmişlerin iradesiyle sınırlandırımaktadır (Doğanay, 2003). Gezi direnişinin de gerekçelerinden biri, halkın, böylesi bir demokrasi anlayışında temsil bulamıyor olmasıydı. Ve halk bu isyanda, hakkı olan şeyi derme çatma ve kendisine söz hakkı dahi tanımayan lütufkar bir 'temsil' ile değil, 'doğrudan' talep etmek istediğini dile getirmişti.

Siyaseten başlayan bu temsil sorunu modern toplumlarda tüm kurumlara ve yapılara, kısacası toplumsalı ilgilendiren her şeye nüfuz etmektedir. Basın da buna dahildir ve hatta bu krizden en çok etkilenen durumundadır. Basındaki temsil anlayışının liberal demokrasilerdeki temsil krizinden bağımsız olmaması ve benzer bir işleyiş sergilemesi, orada da 'eyleyen' öznelerin dışlanması sorununu doğurmaktadır. Anaakımın temsil sistemindeki rolünü belirleyen ölçütün yüksek okur/izleyici kazanma çabası olması ve bunun da reklam ve izlenme kaygısı ile siyasi iktidarın güdümünde olma çerçevesinde şekillenmesi, onun temsil anlayışını da çıkmaza sürüklemektedir. Bu noktada alternatif bir yayıncılığın önemi daha açık bir şekilde hissedilmekte ve görülmektedir.

Express dergisinden Yücel Göktürk'ün derginin habercilik pratiğini özetlerken 'eyleyen öznelere' dikkati çekerek, "Bizim habercilik pratiğimiz 'eyleyen özneler'i konuşturmak üzerine. Mesele özneyi konuşturmak, bizim onun yerine konuşmamı değil" diyerek izah ettiği şey ise, Duncombe'nin alternatif medya kurumlarının en önemli özelliklerinden birisi olarak öne sürdüğü, yazar ile okur, üretici ile tüketici ayrımının bulanıklaşmasına bir örnektir (aktaran Atton, 2002: 23). Express, temsili demokrasilerin karşısına kurucu bir alternatif olarak konulan 'katılımcı demokrasi' modelinin medyadaki timsali gibidir. Ana akım medyadaki üretim ilişkilerine, hiyerarşik düzene ve içerik üretimine karşı bir alternatif olarak Express, 'temsil' noktasında da ayrı yerlerde durmaktadır.

Gelinen noktada Express, 2001 yılında başladığı Post-Express dönemini 2014 yılında sona erdirmiş bulunmaktadır. Yücel Göktürk "Odak Ayarı" isimli 
yazısında bu kararın gerekçesini şu sözlerle açıklamıştır: "Yeni Türkiye'ye (AKP hegemonyasının ifadesi olan) karşı yeni raylar döşemek bir mecburiyet. Yeni zeminler, çoğulcu ve birleşik mücadele zeminleri oluşturmak yeni eylemeyleme biçimleri bulmak pratiğe dökmek... Peki nasıl? Bu geniş katmanlı soruyu, bütünlüklü bir karşılık verebilmek için, faaliyet alanımıza doğru daraltalım. Nasıl bir yayın? Biraz daha daraltalım: Nasıl bir Express?" (Göktürk, 2015). Ekip, tam da bu soruyu yanıtlamak için bir odak ayarı gerektiği düşüncesiyle yayına kısa süreli ara vermek düşüncesindedir. Bu aranın sonrasında format açısından ne tür bir yenilenmenin olacağı ise muallakta bırakılmıştır: Tekrar basılı mevsimlik bir dergiye, e-dergiye veya mevcut web sitesi üzerinden çevrimiçi bir yayına dönüşmek gibi olasılıkların bulunduğu ifade edilmektedir.

Bu noktada Express deneyimi belki de alternatif haber dergiciliğinin geleceği üzerine çözülmeyi bekleyen çok önemli, hatta kilit bir meseleye ışık tutmaktadır. Dergi yönetiminin hiyerarşik biçimde ve sahiplik ilişkisi temelinde işlememesi, esnek ve gayri-merkezi örgütlenme biçimi gibi, yayının demokratik ve katıımcı yapıda olması bağlamında olumlu değerlendirdiğimiz kimi özellikler, bazı handikapları da içinde barındırıyor olabilir mi? Özellikle yayının sürekliliği ve sistematik işleyişi göz önünde bulundurulduğunda, Express'in ara vermesine neden olan sorunların arasında, esnek yapısının ve ona bağlı olumsuz yan etkilerin bulunduğu gerçeği yadsınamaz. Derginin kurucu ekibinden olan Duran'ın ifadesi de bu yargıyı destekler niteliktedir: "Medya mülkiyet yapısı her halükarda bir işverenin sermayesine dayanmadığı için olumlu ama bu yapının maalesef çok da sistematik bir şekilde işleyemediği ve kalıcı olmadığı anlaşıldı. Yönetim tarzının egemen medyanınkinden, haliyle çok farklı, yani demokratik olduğunu da biliyorum. Bu iki nokta önemli... Hatta tayin edici..." (Duran, 2015) Bu bağlamda Express'in ve gelecekte onun takipçisi olabilecek yayınların, hem demokratik işleyiş biçiminden ve alternatif bir içerik üretiminden, hem de alternatif ve bağımsız duruştan taviz vermeden, kalıcılığı ve sürekliliği yakalamanın yolunu nasıl bulacağı, alternatif medya kurumları açısından önemli bir soru olarak öne çıkmaktadır.

\section{Kaynakça}

\section{ADAKLI G. (2006), Türkiye'de Medya Endüstrisi: Neoliberalizm Çağında} Mülkiyet ve Kontrol ílişkileri, Ankara: Ütopya Yayınları.

ADAKLI G. (2010), “Gazetecilik Etiğini Belirleyen Yapısal Unsurlar: Medya ve Kontrol Sorunu", Televizyon Haberciliğinde Etik, Bülent Çaplı ve Hakan Tuncel (Ed.), Ankara: Fersa Matbaacılık, s. 61-96.

AKDAĞ E. (2004), "Darbe İle Başladı, Değişimle Noktalandı", Aksiyon, www. aksiyon.com.tr/aksiyon/haber-9186-26-darbe-ile-basladi-degisimle-noktalandi. html, Erişim Tarihi: 22.09.2013. 
ATTON C. (2002), Alternative Media, Londra: Sage Pub.

BAILEY O.G. CAMMAERTS, B. CARPENTIER, N. (2008), Understanding Alternative Media, Maidenhead: Open University Press.

BULUNMAZ B. (2011), "Holdingleşme Ekseninde Türk Medyasında Tekelleşme Sorunu" Öneri Dergisi, Sayı: 36, s. 237-246.

CEYHAN Ç. (2013), "Alternatif Değil Anarşist: Ahali Gazetesi ve Haber Odasında Etnografi", Sahanın Sesleri: İletişim Araştırmalarında Etnografik Yöntem, İstanbul: Bilgi Üniversitesi Yayınları.

DOĞANAY Ü. (2003), Demokratik Usuller Üzerine Yeniden Düşünmek, Ankara: Imge Kitabevi Yayınları.

DOWNING J.D.H. (1984), Radical Media: The Political Experience of Alternative Communication, Boston: South End Press.

ERYILMAZ T. (2002), "Haber Dergiciliği: 'Bir Tür Hatırlıyorum' Yazısı", Birikim, Sayı: 151-152, s. 211-214.

GÖKTÜRKY. (2014), "Odak Ayarı”, Bir+Bir, http://birdirbir.org/odak-ayari/\#sthash. kdbWiym4.P7euugol.dpuf, Erişim Tarihi: 26.12.2014.

KALYONCU C.A. (2004), Haber Dergiciliği Akis Ille Başlıyor, Aksiyon, http:// www.aksiyon.com.tr/aksiyon/haber-9183-26-haber-dergiciligi-akis-ile-basliyor. html, Erişim Tarihi: 20.09.2013.

KOCABAŞOĞLU U. (1984), "Cumhuriyet Dergiciliğine Genel Bir Bakış", Türkiye'de Dergiler Ansiklopediler, İstanbul: Gelişim Yayınları.

MUTLU E. (1998), İletişim Sözlüğü, Ankara: Ark Yayınları.

OKTAY S. (2009), 12 Eylül Sonrası Solun Teorik Kurgusu içerisinde Yeni Gündem Dergisinin Yeri, Yayınlanmamış Yüksek Lisans Tezi, Yıldız Teknik Üniversitesi Sosyal Bilimler Enstitüsü.

ÖNDEROĞLU E. (2010) Gazeteci Aktan'a Hapis, Express'e Para Cezası, Bianet, http://www.bianet.org/bianet/ifade-ozgurlugu/122521-gazeteci-aktana-hapisexpresse-para-cezasi, (Erişim Tarihi: 15 Aralık 2014).

ÖZGEN M. (2011), "1980 Sonrası Türk Medyasında Gelişmeler ve Magazinleşme Olgusu», http://www.siyasaliletisim.org/dr-bahadr-kaleaas/prof-dr-muratoezgen/221, Erişim Tarihi: 17 Aralık 2014.

SÖZERi C. (2007), Türkiye'de "Bağımsız Haber Dergiciliğinin Ekonomik Sorunları: Nokta Dergisi Örneği", İleti-ş-im, Galatasaray Üniversitesi Illetişim Fakültesi Hakemli Akademik Dergisi, Sayı: 7, s. 103-128.

SUiÇMEZ M. (2009), Dergi Haberciliği ve Nokta Dergisi, Yayımlanmamış Yüksek Lisans Tezi, Selçuk Üniversitesi Sosyal Bilimler Enstitüsü.

ŞAHIN H. (1984), "Haftalık Haber Dergileri”, Türkiye'de Dergiler Ansiklopediler, 
İstanbul: Gelişim Yayınları.

TOPRAK Z. (1984), "Fikir Dergiciliğinin Yüz Yılı", Türkiye'de Dergiler Ansiklopediler, İstanbul: Gelişim Yayınları.

TOPUZ H. (2014), II. Mahmut'tan Holdinglere Türk Basın Tarihi, İstanbul: Remzi Kitabevi.

YAPAR-GÖNENÇ A. (2008), "Türkiye'de Dergiciliğin Tarihsel Gelişimi", İstanbul Üniversitesi İletişim Fakültesi Dergisi, Sayı:29, ss. 63-78.

YAYLAGÜL L. (2009), Kitle İletişim Kuramları: Egemen ve Eleştirel Yaklaşımlar, Ankara: Dipnot Yayınları.

YILDIRIM Y. (2013), Sosyal Forum'dan Öfkelilere, İstanbul: Illetişim Yayınları.

\section{Süreli Yayınlar}

Express, Sayı: 103, 2010a

Express, Sayl: 112, 2010b

\section{Görüşmeler}

Yücel Göktürk, Aralık 2013

Ragıp Duran, Şubat 2015

Merve Erol, Mart 2015 
